\title{
Halal Cat Food for the World Market
}

\author{
Amir H.M.S. ${ }^{1}$, Razauden Z. ${ }^{1}$, Harisun Y. ${ }^{2}$, Ida I.M ${ }^{3}$, Mona Z. ${ }^{4}$, \\ ${ }^{1}$ Faculty of Biosceince and Biomedical Engineering, Universiti Teknologi Malaysia, 81310 UTM Skudai, Johor, Malaysia \\ E-mail:docjitra56@gmail.com /amirhusni@biomedical.utm.my, \\ ${ }^{1}$ Faculty of Biosceince and Biomedical Engineering, Universiti Teknologi Malaysia, 81310 UTM Skudai, Johor, Malaysia \\ E-mail: razauden@fbb.utm.my \\ ${ }^{2}$ Institute of Bioproduct Development,Universiti Teknologi Malaysia, 81310 UTM Skudai, Johor,Malaysia \\ E-mail: harisun@ibd.utm.my \\ ${ }^{3}$ Faculty of Chemical Engineering, Universiti Teknologi Malaysia, 81310 UTM Skudai, Johor, Malaysia \\ E-mail: idayu@cheme.utm.my \\ ${ }^{4}$ Faculty of Education, International Islamic University (UIA), Kuantan Campus, Pahang \\ E-mail: monayap@iium.edu.my
}

\begin{abstract}
Currently, University Technology Malaysia (UTM) is engaged with a well-known private company in Malaysia to develop halal cat food for the world. A team of scientists from UTM was formed for the development of cat food from preparing palatants to producing canned cat and kibbled cat food formulation on a commercial scale to fulfil the vast market demand, as well as to act as contract manufacturer for this private company. Financial aid is made available by the university and Malaysian government. The promising market potential of cat food is estimated to be over USD27 billion with over 7 million tonnes produced in 2013 (35\% of the pet food market). It is expected to grow at $5.5 \%$ in value and $2 \%$ in volume; and this had driven the project to be initiated by UTM. The idea of halal, itself is a selling point to the Muslim consumers and the world at large. The world's Muslim population is estimated to be around 1.6 billion, while the world population is estimated to be at 4.6 billion. The demand for halal products is ever growing with emerging markets in India \& China. In addition, the purchasing power of the Muslims is growing, where between 1990 and 2010, the Growth Domestic Product (GDP) per capita for Muslims globally had risen from a Cumulative Annual Growth Rate (CAGR) of $6.8 \%$ in comparison to global GDP per capita which is only at CAGR of $5.0 \%$. Cat food will come in human contact during feeding, handling, cleaning of feeding utensils under the same washing basin and dishwasher. Many times cat food will engage with human food storage facilities such as in the refrigerator and May to some extent affect the human food chain if it is not halal. Most of the available cat feed produce worldwide is non halal and majority are known to contain residues of porcine, dog materials and blood meal, deem unhealthy and unclean by the Muslims community.
\end{abstract}

Keywords - cat food; halal; Malaysia

\section{INTRODUCTION}

The world's pet food market is valued at USD69 billion and as much as 22 million tonnes had been manufactured in 2013 [1] out of which $30-35 \%$ is dominated by cat food products. Based on Euromonitor report in 2013, there are 650 million of cats and dogs worldwide of which $35 \%$ of that population is cats, and $55 \%$ of them live in Europe \& North America [1].

The demand for clean and quality cat food has been on the rise in recent years since they are aware of the benefits it brings to their beloved animal; where their pets will be healthy and their lifespan prolonged. The only thing that the westerners may not be aware of is the term 'Halal' which indicate that the food is free from any kind of filth, the raw materials are from clean sources and does not contain contaminants.

The use of these animals by products, manufactured from dead, dying, diseased and disabled animals, and also those with drugs residues (sodium pentobarbital which is used to euthanize companion animals) should not be allowed to enter the human and animal food chain [2].

It is anticipated that halal cat food products will not only be for the Muslim market but also the global market. They are guaranteed to be free from all contaminants and 
produced from hygienic raw materials, which is essential for the cats' health.

\section{WHY THE WORLD MARKET NEEDS HALAL CAT FOOD?}

The caption 'halal' is itself is a selling point and frequently used as a strategic marketing tool. This caption is expected to be recognised by Muslims worldwide and accepted without doubt as being safe and clean for food consumption and to handle.

The other factor is demand for halal products is growing due to sizeable and growing Muslim population, estimated at around 1.6 billion (Fig.1) and with emerging markets in India \& China, where the market demand for halal food product is estimated at USD2.1 trillion (NMS Consultancy, 2014) (Fig. 1). In addition, the purchasing power of the Muslims is growing, where between 1990 and 2010, the Growth Domestic Product (GDP) per capita for Muslims globally has risen from a Cumulative Annual Growth Rate (CAGR) of $6.8 \%$ in comparison to global GDP per capita which is only at CAGR of $5.0 \%$ (Fig. 1).

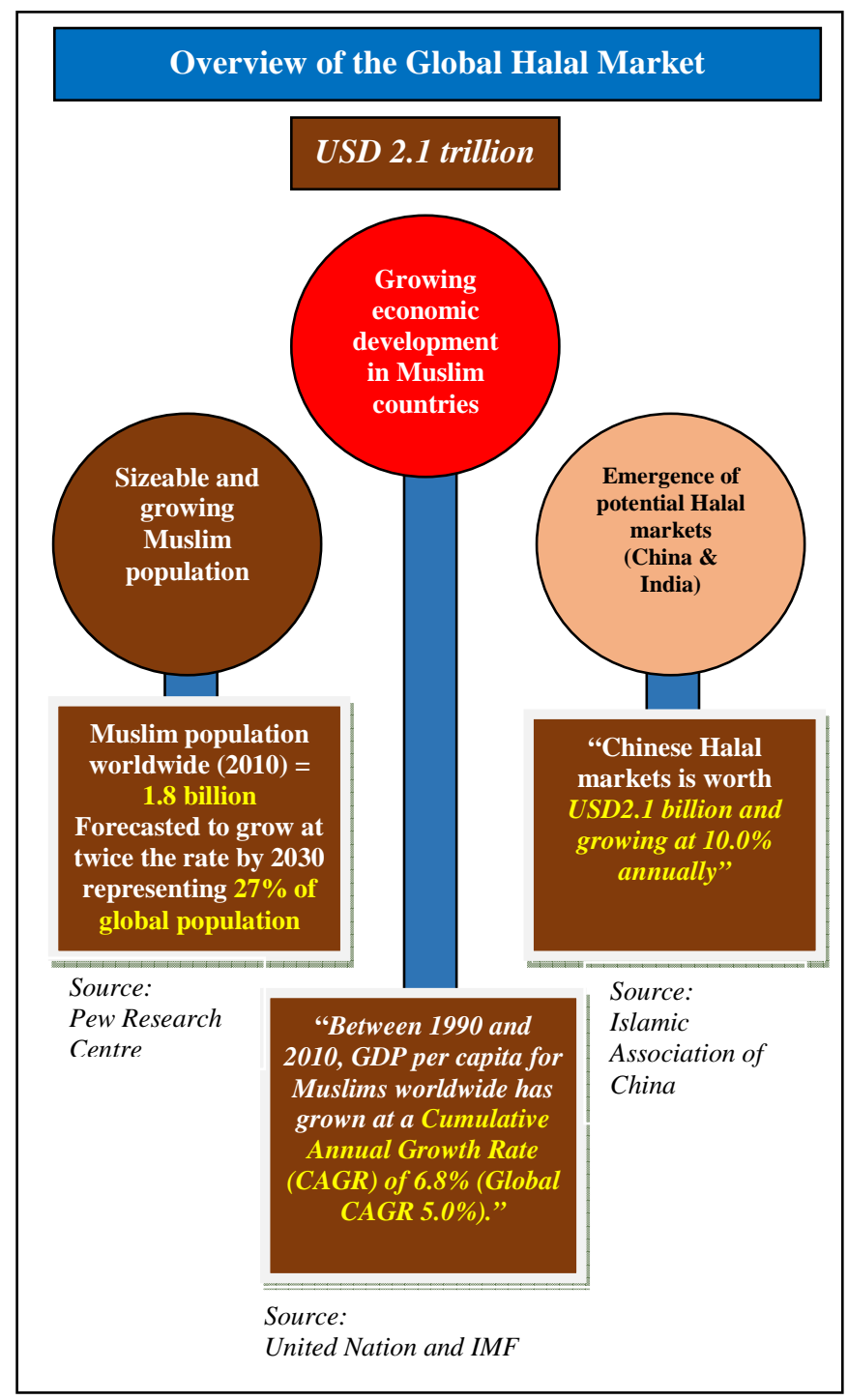

Fig.1 Overview of the Global Market [3]
Cat food will come into human contact during feeding, handling and cleaning of feeding utensils using the same basin and dishwasher used for humans. On many occasions, cat food will be kept together with human food storage facilities such as in the refrigerator. This may, to some extent, contaminate human food if it is not halal.

Halal is an Arabic word which is defined as permissible, legal and allowed. Halal food may include: halal animal which is slaughtered according to Islamic Law, and contains no human parts, non-toxicating, non-hazardous, free from filth, including the equipment used in the food preparation. The ingredient used in the preparation of animal feed must also be halal in order to declare the feed as halal. Halal feed is guaranteed to be free from impurities and any harmful substances.

Most of the available dry cat food produce worldwide are 'non halal' and a majority are known to contain residues of porcine, dog materials and blood meal. In the United States of America alone as many as 100 million hogs are slaughtered annually along with 37 additional millions of cows. Where will all the carcasses go to if not into the animal feed chain? Muslims view pig and its derivatives as unhygienic, unhealthy and are strictly prohibited for consumption. Why this is so, will be discussed in this paper.

\section{SCIENTIFIC BASIS FOR REJECTING NON HALAL ANIMALS \& THEIR BY-PRODUCT}

This paper will only cover the 'non-halal' animals \& their by-products since they are the main basic ingredients used in human and animal food chain that are widely and indiscriminately used in the cat food manufacturing industry. The prohibited materials are pig, dog, blood, carrion and dead animal; all of which used as the main protein source in this manufacturing industry. According to Muslims, all the above are classified as non-halal for consumption and touching those material will require the handlers to undergo certain ritual cleansing procedures.

\section{WHAT IS THE MAIN PURPOSE OF SLAUGHTERING?}

The purpose of slaughtering animals according to Islamic principle is to remove as much blood as possible from the muscles to ensure that the meat derived from the carcass will have longer shelf life prior to processing and preservation. In addition severing the trachea, oesophagus, carotid and jugular veins of the slaughtered animal is a must. This is the best way to remove maximum blood from the animal and to reduce the animal's suffering and speed-up the death process.

Blood is a fluid rich in mineral and has high moisture content which makes it the best medium for microbial growth. The Muslim's way of slaughtering animal is to ensure that minimum blood will be retained in the meat.

Basically cat food is comprised of Protein, Fat, Carbohydrate and Vitamins \& Minerals [4]-[7]. The perfect cat food may contain $50-60 \%$ protein, $30-50 \%$ fat, and 5$10 \%$ carbohydrate, which is the cat's natural diet in the wild [8]. Currently, there is no commercial dried cat food is available in market that emulates the natural diet of the cat. However, attempts have been made to produce canned cat food with $95 \%$ or more protein per weight basis as defined 
by AAFCO "95\% Rule" with the use of ingredient/s derived from animal, poultry or fish [9].

The common list of raw materials used in the cat food manufacturing industry today are: named meat meal, poultry meat meal, poultry by-product meal, meat bone meal, bone meal, fish meal, fresh chicken, fresh beef, offal, fresh fish, beef tallow, chicken oil, vegetable oil, animal fat, animal digest, rice flour, soya bean flour, wheat flour, corn starch, tapioca, corn starch, corn gluten meal, vegetables (fresh/dried fruits \& nuts), permitted colouring, natural \& artificial flavours, preservatives, anti-rancid, fish \& animal natural flavours, vitamin \& mineral. However, the common ones are as listed in Table 1.

TABLE I

BIOLOGICAL VALUES OR QUALITY OF 14 PROTEIN [10]

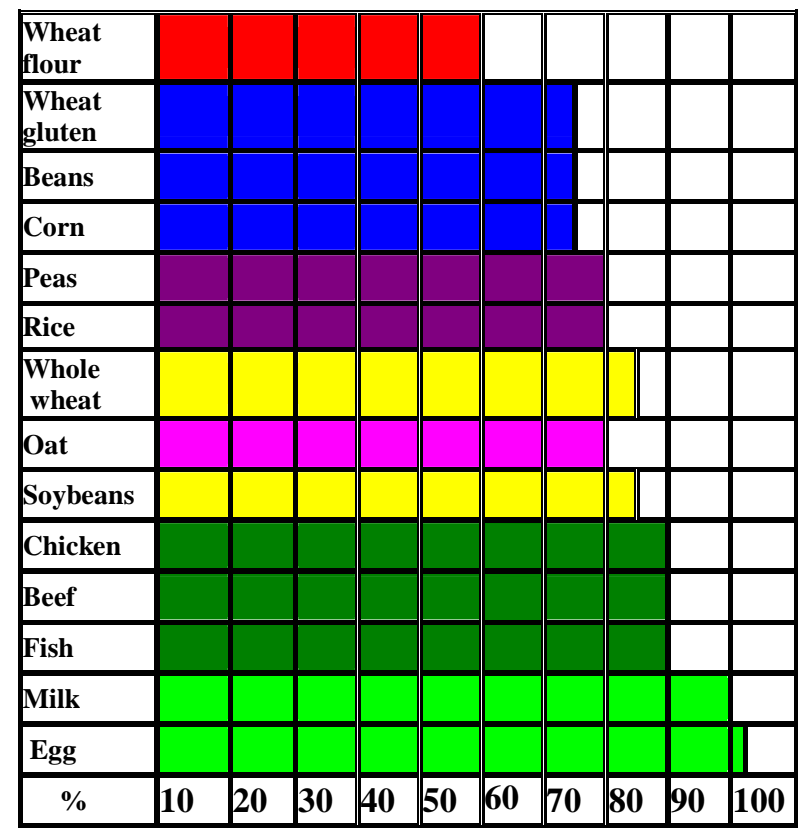

\section{WHAT IS IN CAT FOOD \& THEIR COMPOSITION}

\section{A. Composition of main ingredient in dry cat food / kibbles/ biscuits}

It is interesting to note that all commercial cat food has no published content of carbohydrates on the label. Carbohydrate does not play any important role for the wellbeing of the cat. In fact, it is the source of obesity and feeding high concentration of carbohydrates may induce feline urologic syndrom, due to high accumulation of carbohydrate concentration resulting in Magnesium Ammonium Phosphate crystal precipitation (struvite) [11].

The following formula will be used to calculate the percentage of dry matter and dry matter weight of each nutrient available in the cat food as illustrated in Table II. The carbohydrate concentration in each of the cat food formulation will be revealed for scrutiny [1]. Basic calculation

$$
\text { Dry matter } \%=100-\text { moisture content }
$$

Dry matter weight $\%=\frac{\text { Nutrient }\left(\%_{3}\right)}{\text { Dry want }[\%]} \times 100 \%$
Given:

Guaranteed Analysis for Selected Dried Cat Food (1 kg = USD 9.50)

TABLE II

COMPARISON BETWEEN WET AND DRY CAT FOOD

\begin{tabular}{|l|l|l|}
\hline & $\begin{array}{l}\text { Under Moist } \\
\text { Condition } \\
\text { Figure 2 }\end{array}$ & $\begin{array}{l}\text { On Dry Matter Basis } \\
\text { Figure 5 }\end{array}$ \\
\hline Protein & $35 \%$ & $35 . / 90 \times 100=38.9 \%$ \\
\hline Fat & $17 \%$ & $17 . / 90 \times 100=18.9 \%$ \\
\hline Crude Fibre & $8.5 \%$ & $8.5 . / 90 \times 100=9.4 \%$ \\
\hline Moisture / Water & $10 \%$ & --- Nil--- \\
\hline Carbohydrate & $\mathbf{2 9 . 5 \%}$ & $\mathbf{2 9 . 5 . / 9 0 x 1 0 0 = 3 2 . 8 \%}$ \\
\hline
\end{tabular}

Therefore, the percentage of carbohydrate under moist condition is $100 \%(35 \%+17 \%+8.5 \%+10 \%)=29.5 \%$ (Fig. 2 ), while the dry matter percentage is $100 \%-10 \%=90 \%$. For dried cat food, the difference of availability of protein, fat and carbohydrate under dry matter basis and that under moisture condition is insignificant. This is due to the fact that the moisture / water content in dry cat food may range from $7-12 \%$ (in this case $10 \%$ ). In terms of quality, it is better to feed the cats with wet canned food rather than dry kibbles, however, combining both is another alternative [6].

\section{1) Main Composition of Wet Cat Food}

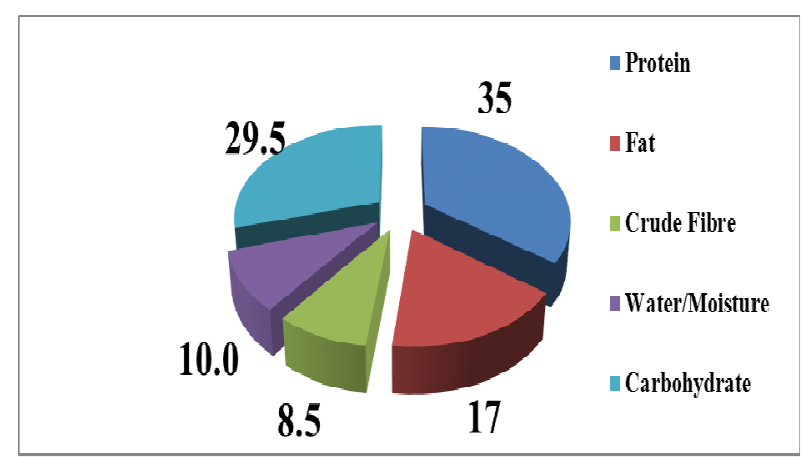

Fig. 2 Percentage of Protein, Fat, Carbohydrate,Water\& Crude Fibre based on Moist Condition in Dry Cat Food

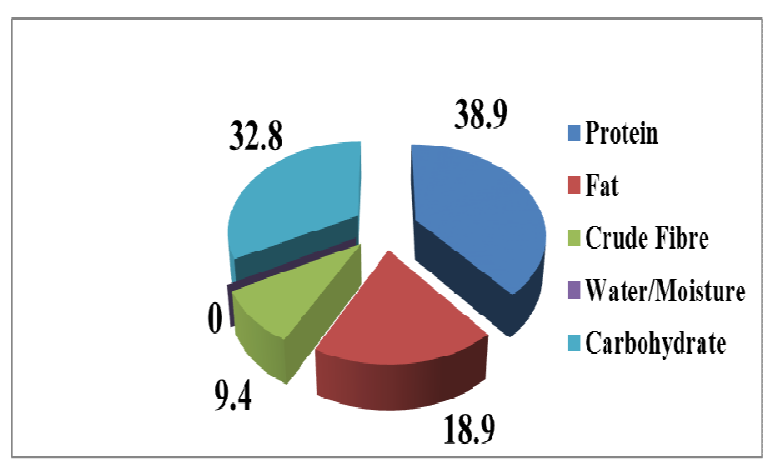

Fig. 3 Percentage of Protein, Fat, Carbohydrate \& Crude Fibre based on Dry Matter Basis in Dry Cat Food 


\section{2) Main Composition of Wet Cat Food / Canned Cat} Food

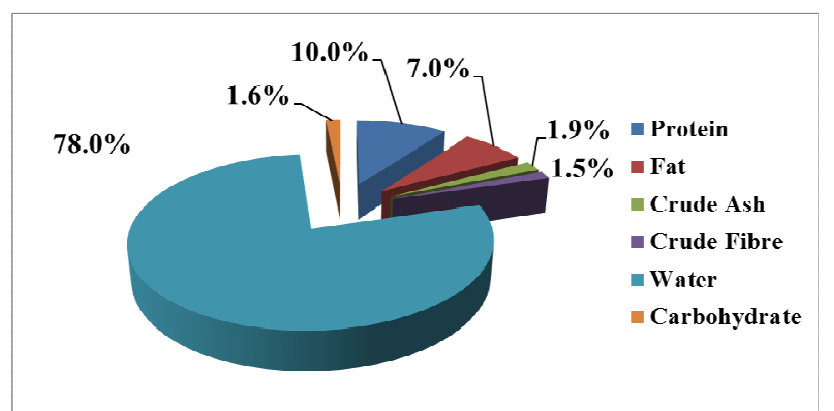

Fig. 4 Percentage of Protein, Fat, Carbohydrate, Crude Ash, Crude Fibre \& Water based on Moist Condition in Canned Cat Food

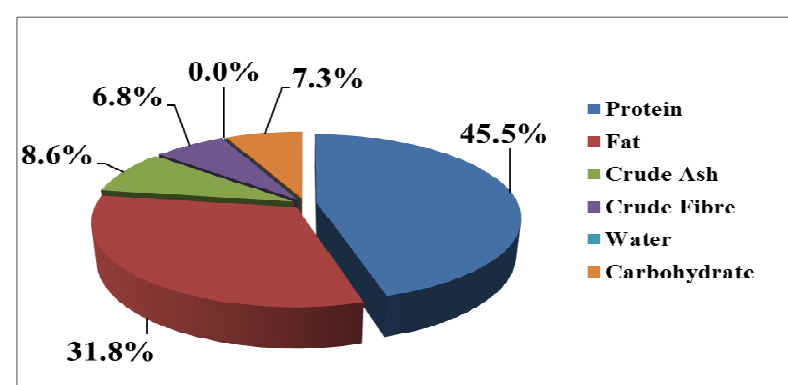

Fig. 5 Percentage of Protein, Fat, Carbohydrate, Crude Ash, Crude Protein based on Dry Matter Basis in Canned Cat Food

\section{CONCLUSIONS}

The halal logo or sign or the written word 'halal' is a good marketing tool to sell cat food products to the world market, when displayed on the packaging. It is well accepted worldwide particularly in the Muslim community and the world at large. Furthermore, it symbolizes cleanliness, purity, free from any prohibited food contaminants and it is safe for consumption. The growing Muslim population of the world is another factor that will help to expand the cat food industry, where it is expected that Muslims prefer cast as their companions rather than dogs. The rise in income of the Muslim population may change their mode of lifestyle, where having a companion animal is part and parcel of the family.

Halal cat food will ensure a high level of safety, comfort and as assurance to the Muslim handlers since they are guaranteed to contain no porcine or dog residues in the ingredients. It is safe to keep along with other human food such those stored in the refrigerator, where human and animal food share common storage compartments.

This joint cooperation between UTM and this established Malaysian food manufacturing company is considered as pioneer research collaboration between the two bodies. The objective is to develop cat food products and their derivatives, specifically halal palatant for canned and kibbled cat food products. This collaboration can be expanded to cover any issues other than animal feed, including human food products. This project is anticipated to be completed within a 3 year period and when the cat food formulation is completed, it will be put into commercial production. Spin-off companies between the two entities will be formed, where all business issues will be resolved between them and the latter will market the product worldwide; where the latter had already established worldwide marketing network. This project is expected to provide extra income to University Technology Malaysia for their future research endeavours and development. This collaborative approach between the universities and the private sectors should be encouraged, where the dependence on government grants by the former can be drastically reduced or even totally eliminated. This symbiotic partnership will enable universities in Malaysia to market their expertise and technological knowhow to the private sectors and bring mutual benefit not only to both parties but also to the development of the country.

\section{ACKNOWLEDGMENT}

We take this opportunity to thank the Chairmen of ADABI-UTM Commercial Halal Cat Food Steering Research Committee, Dr. Salleh Mohd Nor (Tan Sri) and Syed Manshor Syed Mahmood (Dato,) for their kind permission \& the financial facilities made for us to present this paper. We extended out thanks to the Vice Chansellor, UTM, Prof. Ir. Dr. Wahid Omar (Datuk), Prof, Ir. Dr. Azraai Kassim, Deputy Vice Chancellor UTM (Research \& Innovation), Prof. Dr. Jasmy Yunus, the Dean, Faculty of Biosciences \& Medical Engineering for their keen support for this undertaking project.

\section{REFERENCES}

[1] Champion Chloe'. "Key pet food market figures, world outlook and a focus on Asia." 4th Asian Symposium. April 7th 2014. Bangkok, Thailand. SPF Diana. 2014

[2] Martin, A.N. Food Pets Die For. Shocking Facts about Pet Food. New Sage Press, Oregon. Publishers Group West, 800-788-3123. 144pp. 1977

[3] NMS, Consultancy. Lecture notes on certified halal trainers workshop. 10th-16th August, 2014. Centre of Research for Fiqh Science \& Technology (CFiRST), Universiti Technology Malaysia, 81310, Skudai, Johor. 2014

[4] Amir, H.M.S \& Mona, Z. Raw ingredients in cat food manufacturing: Palatability, Digestibility \& halal issues in Malaysia. J.T.R.S.S. Vo.1 No.1:1-15p 2013

[5] Amir, H.M.S, Lam, C.H., Soo A.P., Kumara T.K. \& Mona, Z. Physiochemical properties of premium, standard and economiccommercial cat foods in Malaysia. J.T.R.S.S. Vo.3, No.3. 2014

[6] Amir,H.M.S., Mona, Z, Harisun, Y. Razauddin, M.Z. \& Ida Idayu, M.. Wet and dry (canned \& kibble) cat food in Malaysia. A perspective evaluation. A paper presented the 26th VAM Congress 2014: Challenges of globalisation. Veterinary Services \& Livestock Industries: 2020. Palm Garden Hotel, IOI Resort, Putrajaya Malaysia.

[7] Nurul, A.P., Rumaizi, S., Wan Zahari, W.M., and Amir, H.M.S. Nutritive values of super-premium cat foods in the Malaysian market- A comparative study. A paper presented the 26th VAM Congress 2014: Challenges of globalisation. Veterinary Services \& Livestock Industries: 2020. Palm Garden Hotel, Putrajaya Malaysia.

[8] Peterson, M.E. (2011). Optional protein requirements for older cats with hyperthyroidism [Online]. Available : http//endrocrinevet.blogspot.com

[9] Anonymous, (2007). Get the facts. What's in your dog food? [Online]. Available : http//bornfreeusa.org/facts.php? more $=1 \& \mathrm{p}=359$

[10] Anonymous, (2012). Feline nutrition. Max House. Animal Science Inc. Ridgewood NJ 07451-1581 [Online]. Available: http// maxhouse.com.

[11] Tarttelin, M.F. Specific dietary needs of cats and some endocrine and metabolic disorders. Proceedings Nutrition society of New Zealand 16:83-92. 1991 